\title{
Gambaran Orientasi Masa Depan Remaja Dalam Bidang Pekerjaan Ditinjau Dari Religiusitas dan Motivasi Berprestasi Pada Remaja Desa Sei Banyak Ikan Kelayang
}

\author{
Rita Susanti \\ Fakultas Psikologi Universitas Islam Negeri Sultan Syarif Kasim Riau \\ email: rita.susanti@uin-suska.ac.id
}

\begin{abstract}
Abstrak
Kemampuan individu merencanakan masa depan merupakan hal yang mendasar dalam kehidupan. Remaja dihadapkan pada tugas untuk merencanakan masa depan. Orientasi masa depan bidang pekerjaan merupakan hal yang sangat penting dimiliki oleh remaja dalam merencankan masa depan bidang pekerjaan. Orientasi masa depan dapat dibangun dengan adanya keyakinan yang kuat bahwa Allah akan menentukan tercapainya apa yang direncanakan disertai dengan semangat untuk berprestasi. Tujuan penelitian ini adalah menguji dan membuktikan secara ilmiah mengenai hubungan religusitas dan motivasi berprestasi dengan orientasi masa depan bidang pekerjaan pada remaja. Populasi dalam penelitian ini sebanyak 108 remaja di Desa Sei Banyak Ikan. Teknik pengambilan subjek menggunakan teknik sampling jenuh. Data hasil penelitian ini dikumpulkan dengan menggunakan tiga skala yakni skala orientasi masa depan bidang pekerjaan, skala religiusitas, skala motivasi berprestasi. Analisis data dengan teknik regresi ganda. Berdasarkan Hasil analisis data diperoleh nilai $F=10,917$ dengan nilai signifikansi $p=0,000$ artinya $p$ lebih kecil dari 0,01 dengan sumbangan efektif Adjusted $\mathrm{R}^{2}$ sebesar $15,6 \%$. Artinya hipotesis diterima yakni religiusitas dan motivasi berprestasi dapat memprediksi gambaran orientasi masa depan bidang pekerjaan pada remaja.
\end{abstract}

Kata Kunci: religiusitas, motivasi berprestasi, orientasi masa depan bidang pekerjaan pada remaja.

\section{Description of future orientation of field work viewed from religiosity and achievement motivation in adolescents Desa Sei Banyak Ikan Kelayang}

\begin{abstract}
The ability of an individual plan for the future is fundamental in life. Teens faced with the task of planning for the future. The orientation of the future field of work is a very important thing owned by young people in planning for the future field of work. The orientation of the future can be built with a strong belief that God will determine the achievement of what is planned along with a passion for achievement. The purpose of this study was to test and prove scientifically the relationship between religiosity and achievement motivation and orientation of the future field of work in adolescents. The populations in this study were 108 adolescents in Desa Sei Banyak Ikan. Subject retrieval technique using sampling techniques saturated. Data from this study were collected by using three scales namely the scale of a future-oriented field of work, the scale of religiosity, achievement motivation scale. Data were analyzed by multiple regression techniques. Based on the results of data analysis obtained value $F=10.917$ with a significance value of $p=0.000$ means $p$ less than 0.01 with the effective contribution of $15.6 \%$ Adjusted $\mathrm{R}^{2}$. This means that the hypothesis is accepted that religiosity and achievement motivation can predict the future orientation of the picture area of work in adolescents.
\end{abstract}

Keywords: religiosity, achievement motivation, future-oriented field of work in adolescents.

\section{Pendahuluan}

Remaja adalah generasi muda yang mengemban tugas dan tanggung jawab bangsa dan negara Indonesia di masa yang akan datang. Pada kenyataannya, banyak remaja yang kurang beruntung dibandingkan dengan remaja pada umumnya, seperti kondisi rema- ja di Desa Sei Banyak Ikan Kecamatan Kelayang. Remaja di desa ini banyak yang menganggur, putus sekolah dan harus mencari uang sendiri dengan menjadi buruh di kebunkebun orang lain, seperti buruh pemanen kelapa sawit dan karet. Kondisi remaja di Desa Sei Banyak Ikan disebabkan oleh kondisi status ekonomi yang rendah sebab tidak memi- 
liki lagi lahan pertanian sendiri karena telah dijual kepada masyarakat transmigrasi yang datang kedesa tersebut.

Kondisi remaja di Desa Sei Banyak Ikan ini akan mempengaruhi kemampuan pemecahan masalah pada diri remaja dan ketidakjelasaan orientasi masa depan remaja tersebut. Menurut Hayadin (2005) dalam bukunya peta masa depanku menjelaskan bahwa banyak hal tengah mengancam masa depan muda bangsa Indonesia. Ancaman tersebut pengangguran, putus sekolah, penyalahgunaan narkoba, penyimpangan sosial dan perilaku sek bebas dan sebagainya. Oleh karena itu untuk menanggulangi masalah tersebut perlu adanya perencanaan dan orientasi masa depan yang jelas dalam pekerjaan dan karir bagi remaja.

Orientasi Masa Depan (OMD) merupakan kemampuan seorang individu untuk merencanakan masa depan yang merupakan salah satu dasar pemikiran seorang manusia (Nurmi, 1989). Orientasi masa depan juga mengambarkan bagaimana seorang individu memandang dirinya sendiri di masa mendatang. Gambaran tersebut membantu individu dalam menempatkan dan mengarahkan dirinya untuk mencapai apa yang ingin diraihnya di masa depan. Sadardjoen (2008) menyatakan bahwa orientasi masa depan adalah upaya antisipasi terhadap harapan masa depan yang menjanjikan. Orientasi merupakan bayangan kehidupan kemudian hari secara realitis. Menurut Poole, Cooney, Nurmi dan Green (dalam Raffaeli dan Koller, 2005) bahwa setiap keputusan yang diambil remaja mulai memperhatikan masa depan seperti pekerjaan dimasa depan, pendidikan di masa depan, dan membangun keluarga di masa depan. Sebagai ruang lingkup orientasi masa depan remaja memberikan perhatian dan harapan yang terbentuk tentang masa depan serta perencanaan untuk mewujudkannya.

Orientasi masa depan remaja di bidang pekerjaan memiliki tujuh dimensi yakni evaluasi diri, pencarian informasi, perencanaan, kondisi emosi, kondisi keluarga, optimisme/pesimisme, serta kejelasan karir di masa depan (Agustriani, dkk, 2001). Penelitian yang dilakukan Bandura (dalam Santrock, 2002) juga menyebutkan bahwa terkait dengan prestasi remaja, diketahui kalau prestasi seorang remaja akan meningkat bila mereka membuat suatu tujuan yang spesifik, baik tujuan jangka panjang maupun jangka pendek. Selain itu, remaja juga harus membuat perencanaan untuk mencapai tujuan yang telah dibuat.

Berdasarkan pendapat Nurmi (2004) menyatakan bahwa orientasi masa depan dalam diri seseorang tergambar dalam tiga aspek yakni motivasi, perencanaan dan evaluasi. Aspek motivasi merupakan tahap awal pembentukan orientasi masa depan, dimana remaja menetapkan tujuan berdasarkan perbandingan antara motif umum dan penilaian, serta pengetahuan yang telah mereka miliki. Aspek perencanaan merupakan proses pembentukan masa depan yang kedua, dimana remaja membuat perencanaan tentang perwujudan minat dan tujuan mereka. Sedangkan aspek evaluasi adalah proses pembentukan orientasi mada depan dengan cara melakukan penilaian terhadap tingkah laku yang ditampilkan dan memberikan penguat bagi diri sendiri.

Agar dapat merealisasikan pencapaian atas pekerjaannya di masa depan, dan mendapatkan pekerjaan yang diinginkan, tentunya remaja harus memiliki persiapan atau perencanaan, termasuk di dalam membuat strategi dan yang paling utama adalah memiliki keyakinan bahwa rencana itu mampu tercapai serta kepasrahan yang tinggi pada ketentuan Tuhan Yang Maha Esa. Keyakinan serta kepercayaan pada ketetapan Tuhan merupakan salah satu indikator dari religiusitas. Menurut Glock dan stark (1994) agama adalah sistem simbol, sistem keyakinan, sistem nilai dan sistem perilaku yang terlembagakan yang semuanya itu berpusat pada persoalan-persoalan yang dihayati sebagai sesuatu yang paling bermakna. Religiusitas (keagamaan) adalah kemampuan seseorang dalam menerapkan dan menginternalisasikan nilai-nilai keagamaan ke dalam kehidupanya dan tercermin dalam sikap dan perilakunya.

Religiusitas merupakan kegiatankegiatan yang berkaitan dengan agama dan bertujuan sebagai pengembangan mental individu. Religiusitas dapat diketahui melalui beberapa aspek penting yaitu aspek keyakinan terhadap ajaran agama (aqidah), aspek ketaatan terhadap ajaran agama (syari'ah atau ibadah), aspek penghayatan terhadap ajaran agama (ikhsan), aspek pengetahuan terhadap ajaran agama (ilmu) dan aspek pelaksanaan ajaran agama (amal atau akhlak) (Glock dan Starck,1994).

Berdasarkan penelitian yang dilakukan oleh Marliani (2013) ada hubungan antara religiusitas dengan orientasi masa depan bidang pekerjaan. Hasil tersebut menunjukkan bahwa tingkat pengetahuan yang tinggi dalam berbagai bidang agama akan membuat individu memiliki perencanaan yang matang mengenai jenis pekerjaan yang akan ditekuninya, terlebih islam mengajarkan bahwa bekerja itu merupakan ibadah dan pekerjaan duniawi itu harus dikerjakan dengan sungguh-sungguh. Pengetahuan yang tinggi tersebut membuat orientasi masa depan bidang pekerjaan subjek akan menjadi jelas. Sebaliknya individu yang memiliki tingkat pengetahuan tentang agama yang rendah akan memiliki orientasi masa depan yang tidak jelas. Secara umum 
remaja yang memiliki religiusitas yang tinggi akan berusaha untuk mewujudkan masa depan yang tinggi pula. Kedisiplinan dalam menjalankan agama akan membentuk pribadi yang memiliki perencanaan yang matang.

Orientasi masa depan tiap individu berbeda-beda, meskipun sama-sama berada pada tahap remaja dan duduk dikelas yang sama. Faktor lain yang juga dapat meningkatkan kemampuan remaja dalam meningkatkan orientasi masa depan adalah motivasi berprestasi. Penelitian yang dilakukan oleh Firdhausya (2010) bahwa terdapat hubungan positif yang signifikan antara motivasi berprestasi dengan orientasi masa depan remaja. Dalam mencapai tujuan atau pekerjaan yang diinginkan oleh remaja sangat perlu untuk memiliki motivasi. Menurut Petri \& Goven (2004), munculnya suatu motivasi pada diri seseorang didasari oleh adanya berbagai kebutuhan yang harus dipenuhi. Motivasi merangsang individu untuk beraktivitas, melakukan dengan sungguh-sungguh untuk membangkitkan semangat guna mencapai hasil yang diinginkan, dalam hal ini adalah prestasi. Motivasi memiliki peran dalam menumbuhkan semangat untuk memuaskan kebutuhan-kebutuhan dalam meraih prestasi. McClelland (Petri \& Govern, 2004) menguraikan bahwa konsep motivasi berprestasi muncul dengan adanya need for echievement dalam diri seseorang.

Perencanaan masa depan remaja selain itu remaja harus memiliki motivasi berprestai untuk meningkatkan kemampuan remaja dalam meningkatkan orientasi masa depan dalam bidang pekerjaan. Menurut Heckhausen (1967) menyebutkan motivasi berprestasi yang tinggi akan mendorong remaja untuk meningkatkan dan mempertahankan kecakapan setinggi mungkin dalam segala aktivitas. Berdasarkan paparan di atas, tulisan ini mencoba melihat bagaimana Gambaran orientasi masa depan remaja dalam bidang pekerjaan ditinjau dari religiusitas dan motivasi berprestasi pada remaja di Desa Sei Banyak Ikan Kelayang".

Berdasarkan penjelasan diatas, maka hipotesis dalam penelitian ini adalah : Terdapat hubungan antara religiusitas dan motivasi berprestasi dengan orientasi masa depan remaja dalam bidang pekerjaan.

\section{Metode}

\section{Subjek}

Subjek dalam penelitian adalah remaja di Desa Sei Banyak Ikan Kecamatan Kelayang Indragiri Hulu. Karakteristik dari subjek penelitian ini adalah remaja yang berusia 10 tahun -17 tahun. Teknik pengambilan subjek penelitian adalah purposive sampling yakni pengambilan subjek berdasarkan karakteris- tik subjek yang telah ditentukan oleh peneliti. Jumlah subjek penelitian adalah sebanyak 108 remaja yang berada didesa sei banyak ikan kec. kelayang.

\section{Pengukuran}

Penelitian ini menggunakan penelitian kuantitatif korelasional. Penelitian ini menggunakan tiga skala, yaitu pertama skala ODM menggunakan lima Point skala likert yang dimodifikasi dengan literatur yang ada. Point aitem diambil berdasarkan pengungkapan segala aspek orientasi masa depan remaja dalam bidang pekerjaan, yang dibuat berdasarkan Konsep dari Nurmi (2004), yang menggambarkan 3 proses yakni motivasi, perencanaan dan evaluasi. Skala ODM terdiri dari 12 item dengan daya beda item -0,0240,497 dengan reliabilitas 0,703 . Skala kedua religiusitas yakni pengembangan dari teori Glock dan Stark (1994), dengan menggunakan beberapa dimensi yakni dimensi ritual, dimensi intelektual, dimensi ideologis, dimensi pengalaman dan dimensi konsekuensi. Skala religiusitas terdiri dari 11 item dengan daya beda aitem 0,219-0,621 dengan nilai reliabilitas 0,750 . Skala ketiga adalah skala motivasi berprestasi. Skala ini disusun berdasarkan teori dari Hechausen dan pendapat Santrock yakni motivasi instrinsik dan ekstrinsik. Skala motivasi berprestasi terdiri dari 8 item dengan daya beda 0,103-0,493 dengan nilai reliabilitas 0,511 .

\section{Analisis Data}

Pengujian hipotesis dalam penelitian ini menggunak teknik analisis regresi ganda dengan bantuan program komputerisasi SPSS seri 19 for window.

Hasil

Hasil analisis hipotesis yang diperoleh dari teknik analisis regresi ganda menunjukkan ada hubungan yang signifikan antara religiusitas dan motivasi berprestasi dengan orientasi masa depan bidang pekerjaan pada remaja, dengan nilai $F=10,917$ dan nilai signifikansi $p=0,000$ artinya $p$ lebih kecil dari 0,01 maka disimpulkan bahwa religiusitas dan motivasi berprestasi dapat memprediksi orientasi masa depan remaja dalam bidang pekerjaan, dengan sumbangan efektif Adjusted $\mathrm{R}^{2}$ diketahui sebesar $15,6 \%$. Hal ini dapat menjelaskan bahwa remaja yang memilki tingkat religiusitas yang baik dan memilki motivasi berprestasi yang tinggi, maka akan mudah untuk merencanakan masa depannya dalam bidang pekerjaan.

\section{Pembahasan}

Orientasi masa depan menurut Nurmi 
(1991) menggambarkan bagaimana individu memandang dirinya dalam konteks masa depan. Gambaran ini membantu individu dalam mengarahkan dirinya untuk mencapai perubahan-perubahan sistematis agar dapat mencapai apa yang diinginkannya. Orientasi masa depan dapat terencana dengan baik jika remaja memiliki religiusitas yang tinggi pula. Penelitian yang dilakukan oleh Marliani (2013) bahwa terdapat hubungan positif antara religiusitas dengan orientasi masa depan bidang pekerjaan pada remaja.

Selain itu, menurut pendapat Hasan (2004) bahwa ketika individu memiliki tingkat religiusitas yang sangat kuat idealnya individu itu mampu menjalankan semua yang terkandung dalam ajaran agamanya. Agar dapat merealisasikan orientasi masa depan bidang pekerjaan, tentunya remaja harus mempunyai persiapan dan memiliki kepasarahan serta keyakinan bahwa rencana itu mampu tercapai dengan bantuan Allah SWT. Penelitian lain yang dilakukan oleh Firdhausya (2010) bahwa motivasi berprestasi dapat meningkatkan perencanaan remaja terhadap masa depan bidang pekerjaannya. Hal ini menunjukkan bahwa semakin tinggi motivasi berprestasi yang dimiliki pada seseorang maka semakin tinggi orientasi masa depannya. Motivasi berprestasi adalah dorongan untuk unggul atau berhasil dalam bidangnya ataupun tugas belajar dengan memiliki keyakinan yang kuat dalam diri, keinginan untuk dapat mengatasi kegagalan guna meraih sesuatu keberhasilan ataupun kesuksesan.

Penelitian ini penelitian yang dilakukan oleh Marliani (2013) bahwa tingkat pengetahuan yang tinggi dalam berbagai agama akan membuat individu memiliki perencanaan yang matang mengenai jenis pekerjaan yang akan ditekuninya, terlebih islam mengajarkan bahwa bekerja itu merupakan ibadah. Pengetahuan tentang agama yang baik akan membuat orientasi masa depan bidang pekerjaan subjek akan menjadi jelas. Sebaliknya individu yang memiliki tingkat pengetahuan tentang agama yang rendah akan memiliki orientasi masa depan yang tidak jelas. Tingkat keyakinan yang tinggi akan ketentuan dan ketetapan tuhan, akan menyebabkan individu menyikapi dengan positif segala sesuatu yang menimpan dirinya, akibatnya orientasi masa depan bidang pekerjaanya menjadi semakin jelas.

Tingkat praktek agama yang tinggi juga mampu membuat individu memiliki perencanaan yang matang, sehingga orientasi masa depan bidang pekerjaannya juga ikut jelas. Perencanaan dalam praktek agama salah satunya dapat dilihat ketika seseorang akan melakukan ibadah yang direncanakan, kapan melakukan ibadah tersebut, bagaimana melakukannya dan sebagainya. Secara umum bahwa remaja Desa Sei Banyak Ikan sudah memiliki keyakinan yang baik, namun belum berkembang secara baik, sehingga ini akan berpengaruh terhadap rencana masa depan mereka.

Secara umum, remaja yang memiliki tingkat religiusitas rata-rata akan memiliki motivasi yang sedang/rata-rata atau rendah untuk mewujudkan apa yang dicita-citannya. Hal ini juga terlihat pada remaja di desa Sei Banyak Ikan, bahwa mereka tidak memiliki pengetahuan yang baik mengenai agama, sehingga praktek dan pengalaman agamanya juga semakin sedikit, sehingga mudah berputus asa dengan apa yang ingin dicapai. Ditambah kebiasaan remaja selalu menunda-nunda untuk melaksanakan ibadah. Sebab kebiasaan berdisplin dalam menjalankan ritual keagamaan mampu membentuk pribadi yang memiliki perencanaan yang matang. Disisi lain kemampuan untuk melakukan evaluasi (bermuhasabah) dalam religiusitas juga membuat remaja mampu mengukur kelebihan dan kekurangan yang dimilikinya sehingga mampu berpikir lebih realistis untuk memperoleh pekerjaan yang diinginkannya.

Berdasarkan data penelitian diperoleh bahwa dalam mewujudkan orientasi masa depan yang baik, maka perlu ada dorongan dalam diri remaja untuk berprestasi. Menurut Atkinson menjelaskan bahwa motivasi berprestasi merupakan disposisi berprestasi usaha berhasil yang menganggapnya sebagai dorongan dengan kecenderungan mendekati suatu keberhasilan daripada kegagalan, sebaliknya individu yang memiliki motivasi prestasi yang rendah cenderung mengantisipasi kegagalan. Mengacu pada konsep diatas dapat dipahami bahwa kebutuhan peserta didik akan prestasi belajar disekolah sangat ditentukan oleh motivasi berprestasi yang akan bekerja keras dan sangat mudah atau sangat sukar. Dengan memilih tugas yang sangat sukar berarti remaja mempunyai alasan mengenai kegagalan yang akan dihadapinya, sedangkan tugas yang sangat mudah memberi peluang untuk terhindar dari kegagalan. Remaja di Desa Sei Banyak Ikan masih memiliki motivasi berprestasi yang tergolong sedang hal ini terlihat bahwa remaja masih banyak yang tidak serius dalam mengikuti pelajaran disekolah, kadang kala waktu luang mereka hanya digunakan untuk hal-hal yang tidak bermanfaat, seperti bermain billiar, nongkrong di pinggir jalan dan sebagainya. Hal ini tentu akan berdampak pada perencanaan masa depan dalam bidang pekerjaannya juga tidak berkembang dengan baik. Selain itu, dengan tidak adanya motivasi akan menurunkan minat serta keinginan remaja untuk membuat perencanaan kemasa depan dan merendahkan tekad untuk meraih masa depan atau cita-citanya. 
Motivasi berprestasi sangat berkaitan dengan orientasi masa depan remaja. Dimana orientasi masa depan merupakan sikap optimisme remaja yang berkaitan dengan pemikiran positif, perasaan, harapan-harapan positif terhadap tujuan yang dapat diraih di masa yang akan datang. Remaja yang memiliki optimisme masa depan cenderung memiliki gambaran tentang tujuan-tujuan atau target yang diraih sehingga menyebabkan individu tersebut terdorong untuk melakukan usaha-usaha nyata dalam meraih tujuan yang dimaksud. Motivasi dapat muncul sebagai usaha-usaha dalam diri seseorang dalam menghadapi tantangan karena optimis untuk mencapai keberhasilan dalam belajar ataupun cita-cita masa depan (Dalyono, 2005). Rottinghaus, dkk (2005) mengungkapkan bahwa orang yang optimis salah satunya terlihat dari usaha keras mendapatkan akademik tinggi, serta dorongan beraktivitas dalam tingkatan karir. Remaja yang memiliki dorongan berprestasi dalam dirinya akan lebih berorientasi pada tujuan yang dapat dicapai nantinya. Selain itu, remaja menjadi bersemangat, dan mampu menghadapi berbagai tantangan, serta mampu bangkit dari kegagalan dengan harapan positif dapat mewujudkan tujuan itu. Menurut Mc.Clelland (1995) menyatakan bahwa individu yang memiliki motivasi berprestasi akan memiliki perilaku suka berkeja keras, ulet, membutuhkan umpan balik se- cara nyata, berorientasi masa depan, tidak membuang waktu, optimis, bertanggung jawab dan memperhatikan resiko.

Dorongan merupakan kekuatan penggerak yang membangkitkan kegiatan dalam diri seseorang dan memotori tingkah laku serta mengarahkannya pada suatu tujuan atau berbagai tujuan yang ingin dicapainya. Dorongan-dorongan melakukan berbagai fungsi yang penting dan primer bagi kelangsungan hidup seseorang. Dorongan-dorongan juga mendorong seseorang untuk melakukan banyak tindakan penting yang bermanfaat lainnya dalam usahanya untuk menyesuaikan dan menyerasikan diri dengan lingkungan hidupnya. Salah satu dorongan yang penting pada diri seseorang adalah dorongan berkompetisi (Najati, 1997).

Alqur'an memberikan dorongan yang maksimal bagi manusia untuk berprestasi dalam bertaqwa kepada Allah, berbuat kebajikan, berpegang teguh pada nilai-nilai manusiawi yang universal, dan mengikuti metode ilahi dalam kehidupan, baik dalam hubungannya dengan Allah, hubungan kekeluargaan atau hubungan dengan masyarakat. Kesemuanya ini dimotivasi oleh dorongan agar mereka mendapatkan karunia dan keridhaan Allah dan menerima nikmat masuk syurgaNya, Sebagaimana firman Allah dalam ayatayat alqur'an berikut :

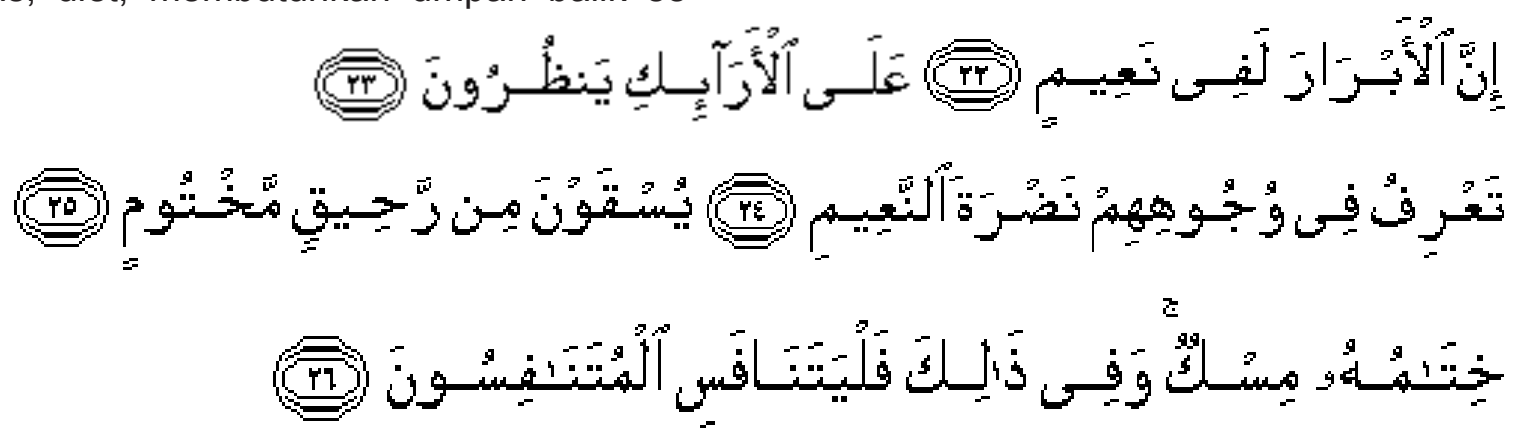

"Sesungguhnya orang yang berbakti itu benar-benar berada dalam kenikmatan yang besar (syurga). Mereka duduk di atas dipan-dipan sambil memandang. Kamu dapat mengetahui dari wajah mereka kesenangan hidup mereka yang penuh kenikmatan. Mereka diberi minum dari khamar murni yang dilak tampatnya. Lak adalah kesturi, dan untuk yang demikian itu hendaknya orang berlomba-lomba" (QS Al-Muthaffifiin, 22-26).

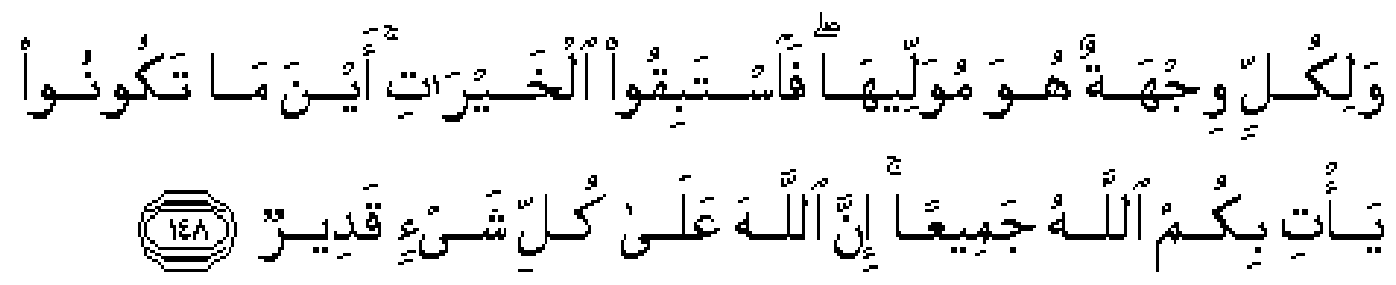

"Dan bagi tiap-tiap umat ada kiblatnyya sendiri yang ia menghadapi kepadanya. Maka berlomba-lombalah kamu dalam berbuat kebaikan. Di mana saja kamu berada pasti Allah akan mengumpulkan kamu sekalian pada hari kiamat. Sesungguhnya Allah Maha Kuasa atas segala sesuatu". (QS Al- Baqarah: 148). 
Sugesti diri atau motivasi internal merupakan salah satu sarana menguatkan kehendak untuk merealisasikan tujuan. Dengan memiliki aspirasi-aspirasi tinggi dan menyempurnakan pandangan seseorang mengenai cakrawala kehidupan yang bersinar, mendorong seseorang untuk membuat sebuah ajakan yang penuh dengan tekad dan ketabahan mencapai tujuan. Sebagaimana ungkapan Ali bin Abu Tolib RA: "Berlombalombalah satu sama lain dalam memperoleh kualitas-kualitas dan martabat-martabat bermanfaat, dalam mengejar identitas-identitas yang besar, dari dalam menghiasi pikiranpikiran yang penuh keagungan, sehingga engkau akan mendapatkan pahala besar dan mencapai hasil-hasil yang penting" (Musawi,
2003).

Siba'i (1995) menyebutkan bahwa dalam Islam ada lima prinsip utama yang menjadi dasar dalam memperoleh hak milik, salah satunya adalah bekerja. Bekerja merupakan bagian dari fitrah manusia dan menjadi salah satu identitas manusia. Dengan demikian, kalau ada manusia yang enggan bekerja atau tidak mau mendayagunakan seluruh potensi dirinya untuk memanifestasikan keimanan dalam bentuk amal kreatif, maka sesungguhnya ia telah menentang fitrah kemanusiaannya dan menurunkan derajat identitas dirinya sebagai manusia. Salah satu ayat yang membicarakan tentang hal tersebut adalah :

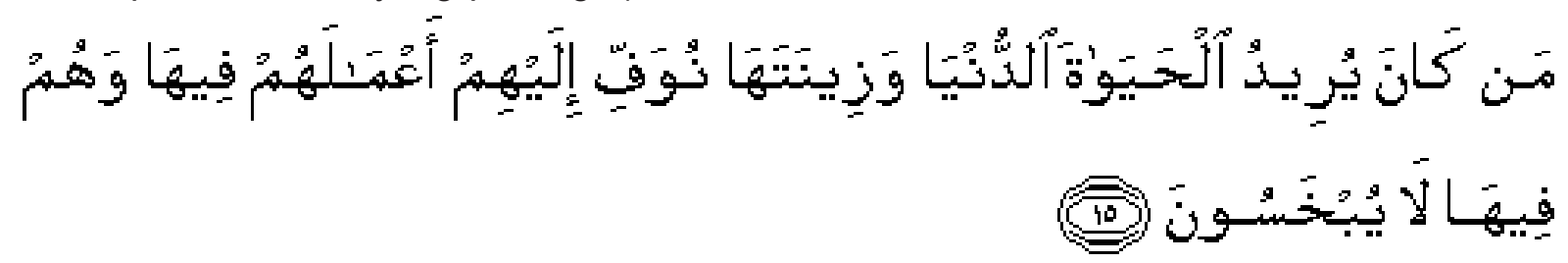

"Barang siapa yang menghendaki kehidupan dunia dan perhiasannya, niscaya Kami berikan kepada mereka balasan pekerjaan mereka di dunia dengan sempurna dan mereka di dunia itu tidak akan dirugikan". (QS Al-Hud: 15).

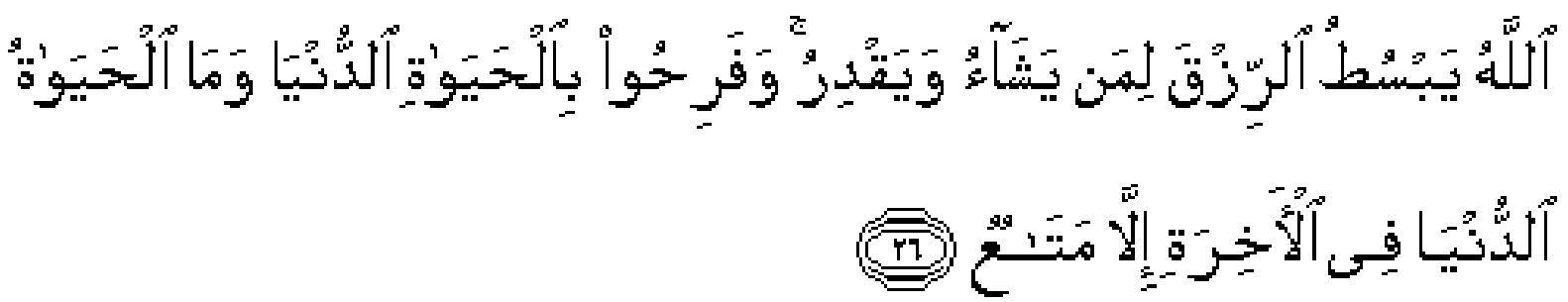

"Allah meluaskan rezeki dan menyempitkannya bagi siapa yang Dia kehendaki, Mereka bergembira dengan kehidupan di dunia, padahal kehidupan dunia ini dibandingkan dengan kehidupan akhirat, hanyalah kesenangan yang sedikit" (QS Al- Ra'ad : 26).

Dalam ayat ini Allah mengajarkan kepada manusia bahwa satu-satunya cara untuk mendapatkan kemakmuran dan harta kekayaan dalam kehidupan dunia adalah dengan bekerja dan berusaha dengan motivasi yang tinggi. Begitulah takdir Allah atas dunia dengan dinamika kehidupannya. Takdir Allah berlaku secara umum, bagi orang mukmin, kafir, musyrik dan munafik. Jika mereka mau bekerja dan berusaha secara maksimal, maka mereka akan mendapatkan nikmat, rahmat dan rezeki dari Allah. Perbedaan di antara mereka adalah terletak dari segi niatnya dan motivasi dari dalam dirinya.

Bekerja dalam pandangan di Islam diungkapkan dalam beberapa pandangan yakni pertama, setiap manusia yang "Mukallaf (dewasa)" memiliki tanggung jawab dalam hidupnya. Pemenuhan tanggung jawab itu antara lain diwujudkan dalam bentuk bekerja. Karena pentingnya pekerjaan bagi seseorang yang mukallaf, maka setiap pribadi semestinya memiliki sejumlah pengetahuan dan keterampilan. Pengetahuan dan keterampilan tersebut bisa dijadikan modal untuk melaksanakan tanggung jawab yang harus dipikulnya. Dalam pandangan islam penguasaan dan keterampilan bekerja disarankan untuk dilatihkan semenjak diri dan memperolah pendidikan (training) yang serius saat seseoarng berusia remaja (10-15 tahun) (Jamal, 2005). Pada fase ini Rasulullah Muhammad SAW juga dilatih berdagang ke negeri Syam, yang menunjukkan bahwa sedang berlangsung proses latihan pada diri nabi muhammad muda untuk mampu bekerja.

Pandangan kedua adalah Islam mendorong seseorang bekerja dan menjauhi ketergantungan kepada orang lain. Banyak hadist yang disampaikan nabi muhammad yang mengungkapkan bahwa sebaik-baik manusia adalah yang bermanfaat bagi orang lain, sejelek-jelek manusia adalah yang menjadi beban bagi manusia lain. Ada hubungan yang sangat signifikan antara religiusitas dan kemandirian. Makin religius seseorang, akan 
makin mandiri. Ini menunjukkan pengetahuan dan penghayatan agama telah dicapai seseorang, maka akan lebih baik dalam berperilaku dan mampu mencapai masa depan secara mandiri. Pandangan ketiga, setiap pekerjaan adalah terhormat sepanjang dilakukan secarasungguh-sungguh dan penuh keikhlasan. dan pandangan keempat, menghindari penggunaan waktu yang tidak berman- faat atau waktu luang dengan bekerja. Setiap orang semestinya selalu bekerja sekalipun ia telah mempunyai kekayaan yang cukup untuk hidup, bahkan termasuk yang hartanya tidak habis untuk tujuh keturunannya.

Orang yang bekerja akan mendapati hasil yang lebih optimal bila berusaha secara maksimal. Ayat suci Alqur'an menyatakan:

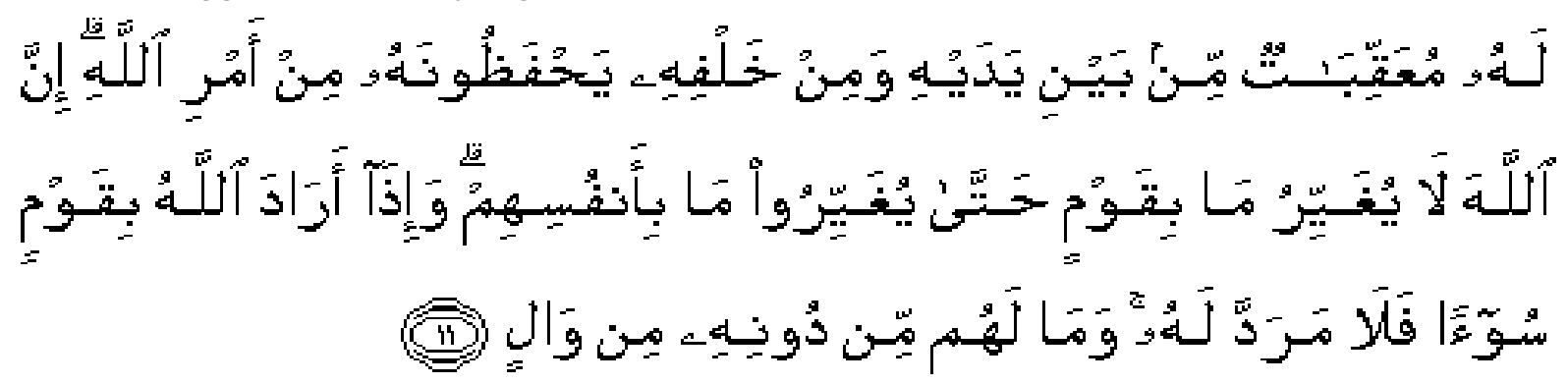

"Bagi manusia ada malaikat-malaikat yang selalu mengikutinya bergiliran, di muka dan dibelakangnya, mereka menjaganya atas perintah Allah. Sesungguhnya Allah tidak merobah keadaan sesuatu kaum sehingga mereka merubah keadaan yang ada pada diri mereka sendiri. Dan tidak ada yang dapat menolaknya, dan sekali-kali tidak ada pelindung bagi mereka selain Allah" (QS Al-Ra'ad :11).

Ayat ini menjelaskan bahwa keadaan yang lebih baik diperoleh jika manusia berupaya untuk mengubah keadaannya. Makin besar usaha yang dilakukan manusia, makin besar pula kemungkinan adanya perbaikan keadaan. Dalam belajar dan bekerja bagi remaja, jika makin besar usaha dan kesungguhan remaja belajar, maka hasil belajar dan mencapaian cita-cita juga akan semakin besar. Dari ini dapat dilihat bahwa gambaran

keberhasilan suatu aktivitas secara optimal dibutuhkan suatu kekuatan dalam jiwa manusia yang dapat menggerakkannya untuk bertindak optimal atau disebut Motivasi berprestasi. Motivasi berprestasi merupakan dorongan kuat pada remaja dalam mengerjakan tugas dengan sebaik-baiknya guna mencapai keberhasilan yang dicita-citakan. Dalam surat Alam Nasyarah : 7 menyebutkan :

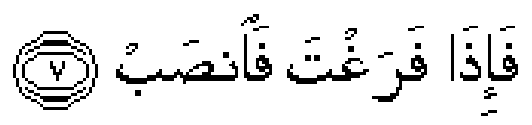

"Maka apabila kamu telah selesai dari suatu urusan, kerjakanlah dengan sungguh-sungguh urusan yang lain" (QS Alam Nasyrah :7)

Ayat diatas menyampikan pesan yang tersirat, yaitu agar manusia memfokuskan diri pada amanat yang telah diterimanya. Dengan penuh konsentrasi, dengan segala potensi, keterampilan, dan pengetahuan, serta kerja keras yang dimilikinya, manusia berupaya untuk mengerjakannya. Motivasi berprestasi dalam Islam lebih menggambarkan niat dan upaya yang sungguh-sungguh untuk mengerjakan tugas, maka akan diperoleh hasil yang sesuai dengan niat dan usahanya.

Remaja desa Sei Banyak Ikan menunjukkan motivasi berprestasi yang masih rendah hal ini bisa disebabkan karena pengaushan orang tua dan pola kehidupan masyarakat di mana remaja tinggal. Penelitian menunjukkan bahwa anak-anak yang memiliki motivasi berprestasi yang tinggi, adalah memiliki orang tua mereka melatih untuk mandiri lebih awal dan menguasai kecakapan-kecakappan tertentu. Bila orangtua selalu menekankan kesungguhan dalam melakukan sesuatu, maka sikap kesungguhan ini akan mempribadi dalam diri anak tersebut. Tugas yang dikerjakan kurang sungguh-sungguh akan menghasilkan dampak bagi keberhasilan anak. Hal ini terjadi pada remaja Desa Sei Banyak Ikan, berdasarkan hasil Focus Group Discussion (FGD) diperoleh pernyataan remaja bahwa mereka tidak memiliki niat yang kuat dalam belajar dan kurangnya orangtua dalam mendukung untuk belajar, dimana telihat dari orangtua tidak pernah menanyakan bagaimana kegaitan sekolah anak, apakah ada Pekerjaan Rumah (PR) atau tidak, bahkan ada orangtua menyebutkan bahwa sekolah juga tidak akan membuat kaya. Hal ini sangat berdampak pada prestasi remaja dan menghambat remaja untuk meraih cita dan menetukan orientasi masa depannya dalam bidang pekerjaan. 


\section{Kesimpulan}

Berdasarkan hasil analisis data dapat disimpulkan bahwa orientasi masa depan remaja dalam bidang pekerjaan dapat diprediksi melalui tingkat religiusitas dan motivasi berprestasi remaja. Hal ini dapat menjelaskan bahwa remaja yang memilki tingkat religiusitas yang baik dan memiliki motivasi berprestasi yang tinggi, maka akan mudah untuk merencanakan dan meraih masa depannya dalam bidang pekerjaan.

\section{Daftar Pustaka}

Agustriani, Hendriati, dkk. (2001). www.ceria. bkkbn.go.id

Dalyono, M. (2005). Psikologi Pendidikan. Jakarta: Rineka Cipta.

Dister. N. S. (1982). Psikologi Agama. Yogyakarta: Kanisius.

Glock, Charles Y, and Rodney Stark. (1994). Religion and Society in Tension. Chicago: Rand McNally and Company.

Hayadin. (2005). Peta Masa Depan Ku. eLSAS : Jakarta

Hasan, M.T. (2004). Dinamika Kehidupan Religius. Jakarta : Listara fiska Putra.

Hekhausen, H. (1967). The Anatomy of Acheivement Motivation. New York: Academi Press.

Hurlock, E. B. (1999). Psikologi Perkembangan: Suatu Proses Pendekatan Sepanjang Rentang Kehidupan. Edisi 5. Jakarta. Penerbit Erlangga.

Hurlock, E. (1999). Psikologi perkembangan Anak, jilid ke satu, (terjemahan : Istiwi dayati). Surabaya: Erlangga.

Jamaal, Abdur Rahman. (2005). Tahapan Mendidik Anak Teladan Rasulullah SAW. Bandung. Penerbit Irsyad Baitus Salam.

Marliani, R. (2013). Hubungan antara religiusitas dengan Orientasi Masa Depan Bidang Pekerjaan Pada Mahasiswa Tingkat Akhir. Jurnal Psikologi, Volume Nomor 2.

Martaniah, Sri Mulyani. (1984). Motif Sosial. Yogyakarta: Gadjah Mada University Press.

Monks, F J \& Knoers. (2002). Psikologi Perkembangan : Pengantar Dalam Berbagai Bagiannya. Yogyakarta : Gadjah Mada University Press.

Musawi, Mujtaba, S. (2003). Hidup Kreatif, Mengendalikan Gejolak Jiwa, Mengubah Problem Menjadi Prestasi dan Kesuksesaan. Depok. Inisiasi Press.

Najati, Ustman, (1997). Alqur'an dan
Ilmu Jiwa. Bandung. Penerbit Pustaka

Nurmi, J.E. (1989). Adolescent's Orientation To The Future: Development Of Interest and Plans, and Related Atributions and Effects in the Life Span Context. Helsinski: Finnish Society of Science.

Nurmi. J.E. (1991). The Development of Future Orientation In Life Span Contect. Helsink: Finnish Society of Science

Nurmi, J. E. et.al. (2003). "Age Different in Adolescent Future-Orientated Goals, Concerns, and Related Temporal Extension in Different Socio culturaL Contexts". Jurnal of Youth and Adolescence. 23. (1994).

Papalia, D. E., Olds, S. W., Feldman, R. D, (2001) "Human development", (edisi ke- 8), McGraw Hill, Inc, Boston,.

Rottinghaus, dkk. (2005). The Career Inventory: A Measure of CareerRelated Adaptability and Optimism. Journal of Career Assessment. Vol 13 No. 1 Febuary 2005. Sage Publications.

Santrock, John W. (2007) a. Remaja Edisi 11 Jilid 1. Erlangga: Jakarta. (2007)b. Remaja Edisi 11 Jilid 2. Erlangga: Jakarta.

Santrock, John.W. (2002). Life-Span development Perkembangan Masa Hidup. Edisi 5, Jilid 2 (terjemah : Achmad Chusairi \& J uda Damanik). Jakarta : Erlangga

Sadarjoen, S. S. (2006). Melulu Orientasi Masa Depan, Cukupkah?. http://www. kompas.com

Siba'i, Mustafa. (1995). Sosialisme Islam, dalam Islam dan Pembaharuan. Jakarta. Raja Grafindo Persda.

Sri Maslihah. (2009). Pelatihan Orientasi Karir dalam Meningkatkan Pengetahuan Orientasi Karir Remaja (Tesis) Bandung: Program Magister Profesional Psikologi Universitas Padjadjaran.

Stevens-Long, J. \& Cobb, N. J, (1983) "Adolescence and early adulthood", May field Publishing Company, California,.

Steinberg, L, , (2009) "Adolescence", (edisi ke-6), McGraw-Hill, Inc, USA.

Sugiyono, (2008). Metode Penelitian Kuantitatif dan Kualitatif: Bandung:Alfabeta.

Wojowasito. S. (1992). Kamus Umum Lengkap Inggris-Indonesia. Bandung: Integrafika Offset. 